\title{
Container characteristics and dengue hemorrhagic fever incidence
}

\author{
Wanti Wanti ${ }^{1}$, Ririh Yudhastuti ${ }^{2}$, Hari Basuki Notobroto ${ }^{3}$, Sri Subekti $^{4}$, Christine Ekawati $^{5}$ \\ Agustina Agustina ${ }^{6}$ \\ 1,5,6 Health Polytehnic Kupang, Minstry of Health, Indonesia \\ ${ }^{2,3}$ Faculty of Public Health, Universitas Airlangga, Indonesia \\ ${ }^{4}$ Fisheries Faculty, Universitas Airlangga, Indonesia
}

\begin{abstract}
Article Info
Article history:

Received Jun 2, 2019

Revised Jul 20, 2019

Accepted Aug 27, 2019

\section{Keywords:}

Aedes sp

Container charactistic

Dengue hemorrhagic fever

ABSTRACT

The condition of Kupang City has low rainfall, low rainy days and includes dry areas, but it turns out that Kupang City had always the highest incidence rate in Nusa Tenggara Timur Province and exceed the national average. This study will analyze the relationship of container characteristic to the incidence of DHF in Kupang City. This study was an observational analytic study with a case control design. The study conducted in 25 villages with total sample 500 people of DHF patients and non DHF patients in Kupang City. The research variables are number of container, water height, water volume, water $\mathrm{pH}$, container type, container location, container material, container lid, and container color which were collected by doing direct observation and measuring the object of study. The collected data was processed and analyzed statistically using Independent $T$ test and Chi Square test. The container conditions related to the incidence of DHF were the amount of container, water $\mathrm{pH}$, and type of container. Whereas the container conditions that were not related to the incidence of DHF are water level, water volume, container location, container material, container cover and container color.
\end{abstract}

Copyright () 2019 Institute of Advanced Engineering and Science. All rights reserved.

\section{Corresponding Author:}

Wanti,

Health Polytehnic Kupang, Ministry of Health, Kupang, NTT, Indonesia.

Email: trivena78@yahoo.com, trivenawanti@gmail.com

\section{INTRODUCTION}

Dengue Hemorrhagic Fever (DHF) is a disease transmitted through mosquito bites and is still a major problem in the world, including in Indonesia. As many 50 million people are estimated to be infected by Dengue Virus every year in the world [1]. Indonesia, as well as the Province of Nusa Tenggara Timur (NTT) is an endemic area of DHF. Kupang City as the capital of NTT Province has the highest dengue cases in NTT. The condition of Kupang City is different from other regions, even though it has low rainfall, low rainy days and includes dry areas (Standardized Precipitation Index<-0.99), but it turns out that Kupang City had always high Incidance Rate (IR) and exceed the national average.

Cases of DHF in Kupang City are not only found in the rainy season but also in the dry season, although there are only a few cases. The IR pattern of dengue in Kupang City does not always follow the pattern of rainfall, as in 2011 rainfall rose but the IR dropped, in 2012 rainfall fell but IR rose even occurred outbreaks in that year, as well as 2013 rainfall rose but otherwise IR DHF down [2-4].

Disease are in principle the result of interactions between Host-Agent-Environment or better known Triangle Epidemiology [5], and for DHF an important elements are dengue virus, Aedes mosquito and humans, and the three elements are influenced by the environment [6]. Disease will always occur if only doing treatment without trying to control risk factors according to the local condition, because the occurrence 
of disease is a local specific phenomenon [7], including the Dengue Fever Incidence. These various factors differ from place to place and cause different degrees of endemicity between places and times.

Environmental condition plays an important role in DHF incidence, such house condition, climate and also water container condition. The condition of container as a breeding place for Aedes $s p$ mosquitoes plays a role in providing breeding grounds and the presence of Aedes sp [8-9], water $\mathrm{pH}$ also have an impact on breeding places selection Aedes sp [10]. Seeing the important role of container and water conditions on the presence of Aedes sp, the knowledge of container characteristic in Kupang City is important to be described in according the prevention of DHF by cutting down the breeding places of Aedes sp. So this study will describe the water container characteristic and also analyze the relationship of container conditions to the incidence of DHF in Kupang City.

\section{RESEARCH METHOD}

This study was an observational analytic study with a case control design. The research was conducted in the 2016 dry season with 12 urban villages and in the 2017 rainy season with 13 villages. There were two samples, the case sample was people who were sick or suffer with DHF and the control sample were people who did not get dengue infection who lived around DHF patients with a radius of 100 meters at the time of the study. The sample size is 20 people per villages so the total sample is 240 people in the dry season and 260 people in the rainy season, or the overall sample is 500 people from 25 villages. Samples were taken by cluster sampling because DHF cases were few and spread in several villages [11-12]. The research variables are number of container, water height, water volume, water $\mathrm{pH}$, container type, container location, container material, container lid, and container color which were collected by doing direct observation and measuring the object of study. The collected data was processed and analyzed statistically using Independent $\mathrm{T}$ test and Chi Square test. This article is part of research that has conducted based on ethical approval from Faculty of Public Health Airlangga University No: 521-KEPK on October 2016.

\section{RESULTS AND DISCUSSION}

This study found the number of water containers varied for each house, which ranged from 1 to 9 and found a significant relationship between the number of container and the incidence of DHF $(\mathrm{p}=003)$, as shown in Table 1. The minimum water level is $1 \mathrm{~cm}$ and maximum is $185 \mathrm{~cm}$, with an average height of container in 53.02 DHF patients and 64.02 not DHF sufferers, but statistically this is not related to the incidence of DHF ( $\mathrm{p}=0.056$ ). The highest volume of water found was $8,079.4$ liters, and apparently there was no relationship between the volume of water and the incidence of BDD $(p=0.206)$. This study found that the $\mathrm{pH}$ of water in container ranged from 5.6-9.9 and the average $\mathrm{pH}$ of container water in DHF patients was lower than in non-DHF patients and statistically this was related to the DHF incidence $(\mathrm{p}=0.034)$.

Table 1. Relationship between number of container, water height, water volume and water $\mathrm{pH}$ with the DHF incidence

\begin{tabular}{ccccccc}
\hline Variables & Sample & Sample (n) & Mean & S.D. & Min-Max & P value \\
\hline Number of & DHF patient & $37(7.4 \%)$ & 2.135 & 1.398 & $1-8$ & \multirow{2}{*}{0.003} \\
container & Non DHF patient & $463(92.6 \%)$ & 1.564 & 1.085 & $1-9$ & \\
Water & DHF patient & $37(7.4 \%)$ & 53.62 & 29.327 & $3-116$ & 0.056 \\
height & Non DHF patient & $463(92.6 \%)$ & 64.03 & 31.923 & $1-185$ & \\
Water & DHF patient & $37(7.4 \%)$ & 255.119 & 228.3446 & $7.9-1101.8$ & 0.206 \\
volume & Non DHF patient & $463(92.6 \%)$ & 467.326 & 1016.8822 & $0.2-8079.4$ & \\
& DHF patient & $37(7.4 \%)$ & 7.089 & 0.5415 & $5.6-8.3$ & 0 \\
Water pH & Non DHF patient & $463(92.6 \%)$ & 7.315 & 0.6279 & $5.9-9.9$ & \\
& & & & & & \\
\hline
\end{tabular}

This research also found that there were $37.8 \%$ drum container or one third compare to total container. There were so many kinds of other container such as bathtub, bucket, water container and dispenser. Statistically, type of container have relation with DHF incidence $(\mathrm{p}=0.022 ;$ OR 2.389), as seen in Table 2.

Table 2 also shows that most water container are in the house, but statistically the water container location is not related to the incidence of DHF $(\mathrm{p}=0.059)$. Most of the water container material was found not from iron, namely from plastic, ceramics, and cement, and there was no relationship between water container material and the incidence of DHF ( $\mathrm{p}=0.101)$. Most water containers in both DHF patients and non-DHF 
sufferers are without lid, and statistically do not show a relationship between the location of water container and the incidence of DHF.

This research found Ae. aegypti was found in 226 water container with the most found in the form of a bathtub $(60.6 \%)$, located in the house $(65.5 \%)$, made from cement material $(47.3 \%)$, open water container (85.8\%), and dark colored container (79.2\%). Ae. aegypti larvae in the dry season was found to be more $(50.9 \%)$ compare in the rainy season. The Ae. albopictus distribution is most commonly found in water container type drum (58.3\%), located outside the home $(66.7 \%)$, made from iron $(58.3 \%)$, open conditions $(83.3 \%)$, dark colored $(91.7 \%)$, and in the dry season $(83.3 \%)$.

Tabel 2. Relationship between type, location, material and cover of water container with DHF incidence

\begin{tabular}{ccccccc}
\hline \multicolumn{2}{c}{ Variables } & DHF Patients & Non DHF Patients & Total & P Value & OR (95\% C.I.) \\
\hline Type of & Drum & $14(37.8 \%)$ & $94(20.3 \%)$ & $108(21.6 \%)$ & \multirow{2}{*}{0.022} & $2.389(1.184-4.821)$ \\
Container & Non Drum & $23(62.2 \%)$ & $369(79.7 \%)$ & $392(78.4 \%)$ & & \\
Location of & Outside & $16(43.2 \%)$ & $126(27.2 \%)$ & $142(28.4 \%)$ & 0.059 & $2.038(1.030-4.030)$ \\
Container & Inside & $21(56.8 \%)$ & $337(72.8 \%)$ & $358(71.6 \%)$ & & \\
Material of & Iron & $12(32.4 \%)$ & $91(19.7 \%)$ & $103(20.6 \%)$ & \multirow{2}{*}{0.101} & $1.962(0.950-4.053)$ \\
Container & Non Iron & $25(67.6 \%)$ & $372(80.3 \%)$ & $397(79.4 \%)$ & & \\
Lid of & Opened & $25(67.6 \%)$ & $372(80.3 \%)$ & $397(79.4 \%)$ & \multirow{2}{*}{0.101} & $0.510(0.247-1.053)$ \\
Container & Covered & $12(32.4 \%)$ & $91(19.7 \%)$ & $103(20.6 \%)$ & & \\
Color of & Dark & $30(81.1 \%)$ & $364(78.6 \%)$ & $394(78.8 \%)$ & \multirow{2}{*}{0.886} & $1.166(0.497-2.733)$ \\
Container & Bright & $7(18.9 \%)$ & $99(21.4 \%)$ & $106(21.2 \%)$ & & \\
\multicolumn{2}{r}{ Total } & $37(100 \%)$ & $463(100 \%)$ & $500(100 \%)$ & & \\
\hline
\end{tabular}

The number of water container in Kupang City was found to be greater in patients compared to non-DHF patients and this turned out to be significantly associated with the incidence of DHF. This result the same with the research in Surabaya that also found a relationship between the number of water container and the presence of larvae13, while the research in Boyolali found that the number of container $\geq 3$ at risk of DHF was 6.75 compared to the number container $<3$ [14].

The water level and water volume in container were found not to be related to the incidence of DHF. Actually there are other factors that are more related to the presence of larvae in container and the incidence of DHF compared to the relationship with height and volume of water. These factors include frequency and how to clean the landfill, the container lid condition, and also $\mathrm{pH}$ of water. It can be seen that the container without lid is at risk with the presence of larvae in landfill at 21.883 compared to container with cover [15], the number of larvae in container and $\mathrm{pH}$ water are also related to the incidence of DHF.

Water is needed for larvae and pupae as a place to live, without water the larvae and pupae will die, as well as mosquito eggs without water will not hatch. The high water level needed by mosquitoes is more than $10 \mathrm{~mm}(1 \mathrm{~cm})$ to lay eggs and hatch, and also to survive [16]. Larvae also need water to drink, such as Ae. aegypti drinks $300 \mathrm{~nL}$ of water every hour [17], so the higher the density of larvae, the more water is needed. Mosquitoes also need water as a breeding place, but in this research the incidence of DHF is not related to volume and height of water in the container but is related to water $\mathrm{pH}$. This is in accordance with the research in Banjarbaru which found that there was a relationship between $\mathrm{pH}$ of water and the incidence of DHF [18]. Previous research has found that tree holes can still be found in Aedes, Culex and Toxorynchites larvae having $\mathrm{pH}$ ranges from 5.0 to 7.5 [19], while at $\mathrm{pH} 8.65$ larvae Ae. aegypti, Ae. Albopictus and Ae. niveus are also still found [20]. The average water $\mathrm{pH}$ in this study was 7.1 in container of DHF patients and 7.3 in container of non DHF patients, and this is still within the optimal $\mathrm{pH}$ range for the growth of Aedes mosquitoes which is 7.4 [21].

This research found that the type of drum container was related to the incidence of DHF with Odds Ratio (OR) 2.389, which means that people who have drum container have a risk of developing DHF 2.389 higher than people who do not have drum container. The type of container drum is not the most container found in the city of Kupang, but the drum container here is related to the incidence of DHF. The drum container is also related to the density of larvae which is related to House Positivity (probability of house positif larvae), Positive Container (probability of container positive larva), Larva in House (number or larva founded in house), and Larva Container Index in House. Study in North Mamuju also found drum container, bathtub, bucket and barrel had the same percentage of $25.52 \%$ and it turned out that the type of landfill was related to the presence of larvae in the container [22].

Int. J. Public Health Sci. Vol. 8, No. 3, Sept 2019: $314-319$ 
This study found the more drum containers, the higher the density of larvae and pupae, and as a result the higher the risk of DHF incidence. Inside part of drum usually made by rough material (iron) so can be a safe place to stick eggs of aedes mosquitoes, so when cleaning the drum, it must be also brushing the inside part of drum regularly once a week. If the drums are not brushed then the eggs will still stick to the drum wall and will eventually hatch into larvae, pupa and adult mosquitoes.

The research in Kupang City did not find any natural container and all of them were man made container. It could be said that the water container associated with the incidence of dengue in Kupang City was an artificial container. This has also been proven in studies in East Purwokerto that there is no correlation between the presence of natural container and the incidence of DHF [23]. Likewise research in Thailand, although Ae. aegypti and Ae. albopictus was found more in artificial container, but statistically there was no difference between the number of Ae. aegypti and Ae. albopictus larvae between artificial container and natural container [24].

Aedes sp mosquitoes are anthropophilic or like human blood so that the breeding place of mosquitoes will not be far from humans, namely in the house or around the house. Ae. aegypti mosquito bites, rests and reproduces more inside the house than outside the home compared to Ae. albopictus which is mostly found outside the home or in the garden near the house [25-27]. The same thing was found in Kupang city, namely Ae. aegypti larvae is more commonly found in homes (65\%) while Ae. albopictus outside the home $(67 \%)$.

Research in Kupang city, although most container were found inside the house, most of Ae. aegypti is also found in the home, while Ae. albopictus is found outside the home, statistically the location of container is not related to the incidence of DHF, however it turns out that the location of container is related to the presence of larvae 15. Unlike the research in Semarang and Banjar Regency, there was no relationship between the location of container and the existence of larvae [28-29].

Mosquitoes and Ae. aegypti is found more at home or more domestic than Ae. albopictus. This is related to the nature of Ae. aegypti more anthropophilic, namely Ae. aegypti female prefers to suck human blood than animal blood to make their eggs stand. In addition to ripening their eggs, blood is also used as an energy source for female mosquitoes [30]. The container made form iron material in this study was not related to the incidence of DHF, which means that the container made of iron is not a risk factor for the incidence of DHF. Most larvae were found in container from cement materials (54\%), as well as Ae. aegypti found in cement container (47\%), but different from Ae. albopictus which is commonly found in iron container (58\%). The container material in this study was not related to the incidence of DHF, but was related to the presence of larvae in the container with OR 2.049 [15]. The relationship of container material with the presence of larvae was also found in studies in Baranangsiang, Bojongkerto and in Semarang [28, 31].

This study in Kupang City found a large portion of container without cover and statistically it was found that no TPA cap relationship was found with the incidence of DHF. This is similar to a study in Semarang which also found that the habit of closing container was not related to the incidence of DHF [32]. This is different from the study in Palangkaraya which found a close relationship with the incidence of DHF [33]. Female mosquitoes are more interested in container that are not closed and especially those located in places protected from sunlight to lay their eggs. However, closed container is not tightly favored by female mosquitoes as a place to lay eggs, because with the lid rarely installed properly, the space inside is relatively darker than the open landfill and access to and out of the container remains compared to closed container [34].

Likewise the research in Kupang City, although the presence of the lid on the container was not related to the incidence of DHF but it was related to the presence of larvae with OR 21.883, which means that the container was closed at risk of larvae infestation of 21.883 times more high compared to being tightly closed [15]. The existence of the lid will not be a risk factor for the presence of larvae, including the incidence of DHF, if the action to clean the container is carried out routinely at least once a week. If the procedure for cleaning the landfill is done more than once a week, it is possible that the eggs that have hatched into larvae can complete the praimago stage until they become adult mosquitoes before the container is cleaned. The study found $57.6 \%$ of respondents cleaned container at least once a week, and as many $42.4 \%$ cleaned container after more than one week. How to clean the container of some people $(17 \%)$ is also still not correct, that is just replacing the water with new water without brushing the inside wall of container, so even though it is often cleaned but if it is not correct then this allows Aedes eggs to stick to the walls of the container and if the container is filled with water then within one day the eggs can hatch and the container remains positive for the larvae. Although there is no significant relationship between the frequency of cleaning the container and the incidence of dengue fever, this is because container in DHF patients and not DHF patients is almost the same as the percentage of frequency of cleaning the container in each week. However, if this is left in the long run, the probability of a positive for larvae is higher than if the container is 
routinely cleaned. So here the container still needs to be cleaned regularly but in the right way ie. to brush the wall and rinse with water to clean the inside of the container.

Female mosquitoes are more interested in dark container and especially those located in places protected from sunlight to lay their eggs [26]. This study found that most Aedes sp larvae were found in dark-colored container $(78.8 \%)$, but it was found that container color was not be related to the incidence of DHF. Previous research in Barangsiang and Bojongkerto also found no correlation between container color and the presence of larvae [31]. Mosquitoes prefer dark colors because the ability to illuminate light from lower dark provides comfort for mosquitoes. This study found that the color of container was not related to the incidence of DHF. This is because not all existing larvae and pupae will become adult mosquitoes because of the death of larvae and pupae due to container immediately cleaned up before all larvae and pupae finish the preimago stage, so that the number of larvae cannot be assumed immediately the risk of dengue incidence.

\section{CONCLUSION}

Based on the results of the research, it was concluded that the container conditions related to the incidence of DHF were the amount of container, water $\mathrm{pH}$, and type of container. Whereas the container conditions that were not related to the incidence of DHF are water level, water volume, container location, container material, container cover and container color. The community is not expected to always clean the landfill at least once a week by rubbing the inner walls of the small-sized container. Large container sites need to be controlled for the existence of larvae by taking larvae at least once a week, giving abate or larvae-eating fish. In addition, there is a need to reuse large container that are no longer used so that they do not become mosquito breeding sites.

\section{ACKNOWLEDGEMENTS}

Thank you to the Ministry of Health Republic of Indonesia, the Director of Kupang Health Polytechnic and the Head of Kupang Environmental Health School who have provided material and finance so that this research can be carried out well. Thank you also to the Head of Kupang City Health Office and Staff, as well as to the local government in Kupang City who have given permission and facilitated data collection in the community. We also say thank you to the people in Kupang City who have received with open arms and who have provided all information related to this research.

\section{REFERENCES}

[1] Unicef, UNDP, World Bank, WHO. Dengue: Guidelines for Diagnosis, Treatment, Prevention and Control. Geneva: WHO; 2009.

[2] BMKG NTT. Climate Data in Kupang. Kupang; 2016.

[3] BMKG NTT. Summer Forecast Season 2016. Season Zones in NTT. Kupang: Kupang Lasiana Climatology Station; 2016.

[4] Health Office Kupang City. Recapitulation of Surveilance Data from Kupang City. Kupang; 2015.

[5] Gordon JE. The Epidemiology of Accident. American Journal of Public Health Research. 1949;39:504-15.

[6] Ditjen PP \& PL. Guidelines for Dengue Fever Control in Indonesia. Jakarta: Kemenkes RI; 2013.

[7] Achmadi UF. Regional based disease management. Kesmas: National Public Health Journal. 2009;3(4):147-53.

[8] Ishak H, Abbas A. Analysis of density factor of Aedes aegypti Larva and Endemisitas Dengue Fever disease in Bulukumba district, South Sulawesi. In: Proceedings of the National Mosquito Day Seminar 2009 "Community participation in integrated mosquito control Program" Bogor; 2009.

[9] Djati AP, Widiastuti D. Several Environmental Factors Related with Endemicity Status of Dengue Haemorrhagic Fever. Health Science Indonesia. 2012;3(1):27-30.

[10] Dom NC, Ahmad AH, Ismail R. Habitat Characterization of Aedes Sp . Breeding in Urban Hotspot Area. Procedia -Social and Behavioral Sci [Internet]. 2013;85:100-9. Available from: http://dx.doi.org/10.1016/j.sbspro.2013.08.342

[11] Usman H, Akbar PS. Introduction to Statistics. Jakarta: Bumi Aksara; 2009.

[12] Medical Research Institute \& Dengue Coordination Unit. Practical Manual and Gudelines for Dengue Vector Surveilance. Sri Lanka: Medical Research Institute \& Dengue Coordination Unit; 2011.

[13] Yudhastuti R. Relations of environmental conditions, containers and attitude of the community with the existence of Aedes Larvae in the area of Endemic DBD in Surabaya. Jurnal Kesehatan Lingkungan. 2005;1(2):40. 
[14] Azizah GT, Faizah BR. Analize Risk Factors of Demgue Hemorrhagic Fever in Mojosongo Village Boyolali District. Eksplanasi. 2010;5(2):1-9.

[15] Wanti, Yudhastuti R, Yotopranoto S, Notobroto HB, Subekti S, Umniati SR. Container Positivity and Larva Distribution Based on the Container Characteristic. International Journal of Public Health Science (IJPHS) [Internet]. 2017;6(3):237-42. Available from: http://www.iaesjournal.com/online/index.php/IJPHS/article/view/16336

[16] Hopp MJ, Foley JA. Global-Scale Relationships Between Climate and the Dengue Fever Vector, Aedes aegypti. Climatic Change. 2001;48:441-63.

[17] Beyenbach KW, Hagerdorn HH. Osmotic and Ionic Regulation by Mosquitoes. 2nd ed. Marquardt WC, editor. California: Elsevier Academic Press; 2004. 347-361 p.

[18] Ridha MR, Rahayu N, Rosvita NA, Setyaningtyas DE. The Relation of Environmental Condition and Container to The Existance of the Aedes aegypti Larvae in Dengue Haemorrhagic Fever Endemic Areas in Banjarbaru. Jurnal Buski. 2013;4(3):133-7.

[19] Chitra S, Ravindran K, Rajkuberan C, Janagaraj K, Sivaramakrishnan S. A Survey Report on Baseline Data of Mosquito Distribution in Tree Holes of Discrete Ecosystem During Different Seasonal Patterns. Acad J of Entomol. 2014;7(2):70-5.

[20] Azmi NNM, Saad AR. Spatial Distribution and Habitat Characterization of Aedes Mosquito Larvae in Dengue Hotspot Areas on Penang Island. In: The 7rd International PSU-UNS Conferences on Bioscience. 2010. p. 134-6.

[21] Joseph AO, Adepeju S-OI, Omosalewa OB. Distribution, abundance and diversity of mosquitoes in Akure, Ondo State, Nigeria. Journal of Parasitology and Vector Biology [Internet]. 2013;5(10):132-6. Available from: http://www.academicjournals.org/JPVB

[22] Gafur A, Saleh M. The Relationship of Water Shelter with the Existence of the Aedes aegypti Larvae in the Residential Type E Motu Village Baras Subdisrict North Mamuju District. Higiene. 2015;1(2):92-9.

[23] Kanigia TE, Cahyono T, Gunawan AT. Risk Factors of Dengue Fever incidence in East Purwokerto Subdistrict of Banyumas District Year 2016. Keslingmas. 2016;35(Des):278-396.

[24] Wongkoon S, Jaroensutasinee M, Jaroensutasinee K, Preechaporn W, Chumkiew S. Larval Occurrence and Climatic Factors Affecting DHF Incidence in Samui Islands, Thailand. World Academy of Science, Engineering and Technology. 2007;19(9):381-6.

[25] Ditjen PP \& PL. Prevention and Eradication of Dengue Fever in Indonesia. Jakarta: Ministry of Health RI; 2005.

[26] Ditjen PP \& PL. Guidelines of Entomology Survey Dengue Haemorhagic Fever and Aedes Mosquito Identification Key. Jakarta: Kemenkes RI; 2013.

[27] Rozendaal JA. Vector Control. Geneva: WHO; 1997.

[28] Ayuningtyas ED. The Difference between Aedes aegypti Larvae Existance Based on Container Characteristic in endemic region of Dengue Hemorrhagic fever. Unnes; 2013.

[29] Hidayah N, Rahmawati D. Bio-Physicochemical Markers of the Aedes aegypti Breeding Water in Endemic and Non Endemic Area. International Journal of Public Health Science (IJPHS). 2019;8(2):9-15.

[30] Eldridge BF. Surveilans for Arthropodborne Disease Medical Entomological. Netherland: Kluwer Academic Publisher Derdreht; 2004.

[31] Sulistyorini E. The determining factor for the Existence of Aedes spp. in the Highest and the Lowest Region of Dengue Hemorhagic Fever Endemic in Bogor City. IPB; 2016.

[32] Winarsih S. Relation of House Condition and Mosquito Nest Eradication with The Dengue Hemorrhagic Fever Incidence. Unnes Jurnal of Public Health. 2013;2(1):2-6.

[33] Richwanto F, Hestiningsih R, Saraswati LD. Relation between the Existance of Aedes aegypti Breeding Place and The Dengue Hemorrhagic Fever Incidence in Palangkaraya Year 2012. JKM. 2013;2(2):16.

[34] Soedarmo. Dengue Fever (Dengue) in Children. Jakarta: UI Press; 1988. 